\title{
Exploration Disclosures of Internal Control as the Impact of Earnings Quality and Audit Committee
}

\author{
Hisar Pangaribuan *1, Raynald Wilbert P. Donni ${ }^{2}$, Oluwatoyin Muse Johnson Popoola ${ }^{3}$, \\ Jenny Sihombing ${ }^{1}$ \\ ${ }^{1}$ Adventist University of Indonesia, Bandung, Indonesia \\ 2 Ernst \& Young, KAP Purwanto Sungkoro \& Surja, Indonesia \\ 3 Tunku Puteri Intan Safinaz School of Accountancy, Universiti Utara Malaysia
}

\begin{abstract}
Information disclosure carried out by management as an appointed agent is increasing in importance and hence, a source of concerns to users. It is widely believed that information received by the stakeholders should be appropriate and sufficient for useful decision making, especially in the era of the Fourth industrial revolution. An appropriate and sufficient disclosure in the Annual report indicates a reflection of the effective implementation of the company's operational, strategic, financial and compliance objectives that have been carried out by the management. This study employed secondary data obtained from the annual report for the banks listed in the Indonesia Stock Exchange (IDX). The data for internal control disclosure was observed through a content analysis approach by calculating the internal control system index obtained in the annual report. This study has shown that companies with high earnings quality report more openly convey the application of internal controls system disclosure. This study demonstrated that company with the high characteristics of the audit committee would significantly increase disclosure of internal controls system than a company without audit committee. Supervision, as one of the internal controls established by the management, enhances the performances of the audit committee in ensuring compliance through full disclosure of the financial statements. Thus, restoring users' trust and confidence in making informed and useful decisions on information emanating from the management.
\end{abstract}

Keywords: Disclosure, Audit Committee, Earnings Quality, Independence, Expertise.

JEL Classification: M42, F40, G30

Paper Type: Research

* Corresponding author: E-mail: pangabhsr@gmail.com 


\section{INTRODUCTION}

Information disclosure to the public becomes very important as a form of transparency that can reduce the occurrence of information asymmetry (Mensah, 2016). Understanding the different information about the state of the company between the management who has more information about outside parties causes the information asymmetry (Scott, 2003). The publication of the Sarbanes-Oxley Act (2002) requires public companies to make disclosures, including the implementation of the company's internal controls. The effect is aimed at restoring public confidence in the capital market after the case of Enron companies in the United States that present made-up financial statements for short-term profits (Boddy, 2017). A prior study in China shows that internal control weakness disclosures can provide useful information to users as an alternative indicator of earnings quality, improve financial reporting quality, and strengthen internal management, such as preventing fraud and embezzlement (Ji et al., 2017). Thus, it encourages the reporting of internal controls to be well integrated into companies incorporated in China.

According to the results of the ASEAN Corporate Governance Association survey, Indonesia is next to Vietnam as countries with the lowest levels of disclosure and transparency (Asian Development Bank, 2014). For instance, the literature revealed a bank that fails to make real disclosures of profits on the financial statement but reports a decrease in assets and losses to the public and Jakarta Stock Exchange (Billet et al., 2016). On the other hand, the internal control systems can provide confidence that shows the company's goals are achieved as a result of the company's performance. Therefore, Indonesian public companies are required to implement and disclose their internal control systems. Although, they are still not very detailed in the description, at least the disclosure of internal control systems includes financial and operational controls, as well as compliance with other laws and regulations and fair review of the effectiveness of internal control systems (Capital Market Supervisory Body, 2012). With the era of regulation of the internal control disclosure, there is a likelihood of restoring the public trust on the financial statements.

The presentation of relevant accounting and financial information for the stakeholders represents an integral part of the transparency and accountability thrust for the effective implementation of corporate governance (Choi \& Meek, 2011; Vakilifard \& Mortazavi, 2016), as a form of adequate management and supervision (Agyei, 2016). For this purpose, the role of the audit committee as a supervisory organ of financial reporting and implementation of the internal control system must be improved, through informed communication, articulated and well-designed procedures to enrich the knowledge of the stakeholders about the company's operations (Leng \& Ding, 2011).

Regulations in Indonesia require at least three members of the audit committee from independent commissioners and external parties or public companies as well as at least one of the member should be an expert with accounting and finance educational background (Financial Service Authority Regulation (FSAR) No.55/POJK.04/2015). The intention of FSAR may perhaps aim at monitoring internal control over company performance, which the general public agrees can be more objective and convincing to right the wrong regarding the composition of the audit committee. The more significant number of audit committee members can improve the supervisory function, and the disclosure of internal control systems (Zhang et al., 2007).

Guo and Liu (2015), in their study, stated that mandatory disclosures could reduce earnings management and improve earnings quality. Presentation of financial statements related to earnings reflects the information disclosure on the company performance. If financial statements are opportunistic, then the quality of earnings becomes low. Highquality earnings can increase stakeholders' trust as a form of disclosure based on effective 
internal control (Leng \& $\mathrm{Li}, 2011)$. The quality of internal control is associated with financial or non-financial information. Therefore, the quality of earnings is recognised to be high, assuming the disclosure of internal control weakness is established in respect of accounting and non-accounting information. This study agrees with Ji et al. (2017) work that the quality of earnings possesses a strong relationship with the internal control disclosure.

The existence of an audit committee in the company is expected to ensure effective monitoring of the company's internal control activities in order to increase investors' confidence in the financial statements (Teoh \& Wong, 1993). Audit committee members who have expertise in finance and accounting will be able to improve the quality of financial statements (Suprianto et al., 2017). Furthermore, a prior study found that an efficient audit committee characteristics will support an excellent supervisory function to improve the quality of corporate earnings (Gao \& Huang, 2016), which shows the implementation of the company's internal controls (Leng \& Li, 2011). Some studies revealed the significance of the disclosure of the company's internal controls in ASEAN, which includes Indonesia (Asian Development Bank, 2014; Billet et al., 2016). Hence, the motivation to research earnings quality, characteristics of audit committees, and internal control disclosure.

\section{LITERATURE REVIEW AND HYPOTHESES DEVELOPMENT}

\subsection{Literature Review}

Granting the separation of functions between the owners and management as the company manager is the underlying mechanism of the entity requires a further performance assessment for the management. Furthermore, supervision is carried out to ensure that actions by the management are oriented towards the interests of the owners of the company. Although, the effect portends an increase in the agency costs (Godfrey, 2010). According to Said et al. (2009), the existence of an audit committee can help to conduct more effective supervisory function, thereby reducing agency costs and improving the quality of the company's financial statements and the quality of earnings. In addition, the existence of an independent audit committee member knowledgeable in accounting and auditing can ensure a better quality of the presentation and disclosure of the financial statements (Gao \& Huang, 2016).

The internal control system entails a process designed to assist in achieving operational effectiveness and efficiency, reliability of reporting on financial statements to meet the criteria, compliance with applicable regulations and laws by involving the board of commissioners, management and other personnel. The internal control system can assist management in monitoring and ensuring the success of the company's operational activities. It aims at covering the weaknesses and limitations of personnel, reducing the possibility of misstatements due to error or fraud, assisting the auditors in determining the sampling methods and size, and the audit methodology to be applied, and assisting auditors in ensuring effectiveness in audit engagement work in accordance with international financial reporting standards, international audit standards, international standards on quality control and relevant acts (Romney \& Steinbart, 2012). The achievement of the effective internal control system must be expressed as a form of transparency in conveying information based on the regulations and information disclosure procedures (Russo et al., 2015).

Investors are parties that need appropriate and sufficient disclosures (for example, key audit matters), including disclosures in the company's internal controls (Cavelius, 2011). On the other hand, management disclosure of relevant, reliable, accurate and correct 
information serves as evidence of excellent performance to stakeholders (Ismail \& ElShaib, 2012).

The internal control systems about information disclosure plays an essential role for shareholders to oversee managers in the presentation of financial statements (Cheng et al., 2013), thus the disclosure of the internal control system to the general public cannot be over-emphasised most notably to the stakeholders in making decisions regarding trust and investment (Spira \& Page, 2010). Interested parties need certain information to be able to assess the possibility of risks occurrence, and the factors that can be detrimental outside the scope of disclosure activities by the auditor. In addition, it is germane for an investor in making useful decisions to consider complete information through disclosure of an internal control system (Hooghiemstra et al., 2015).

There are two types of disclosures relevant to the work of an independent auditor when conducting the internal control system examination, namely: (a) disclosure controls, and (b) disclosure procedures over financial reporting. Disclosure controls and procedures explain various processes and controls in providing company disclosures in accordance with the standards and the Securities Exchange Act. Whereas, internal controls over financial reporting is part of disclosure controls and procedures that are more focused on financial statements (Grant Thornton LLP, 2009). An internal control report must guarantee management's responsibility for developing and maintaining a proper control structure (Gad, 2015).

Referring to the benefits generated by the disclosure of the internal control systems, effective and efficient implementation are non-negotiable. Paletta and Alimehmeti (2016) argued that providing compensation to the CEO and CFO does not guarantee the effectiveness of the internal control system. Instead, it can create good corporate governance practices.

Disclosure of internal control information for companies listed on the Stock Exchange in Indonesia is regulated. Because of the Act of the Chairman of Capital Market Supervisory Body Kep-431/BL/2012 No. X.K. 6 Article 2 Letter G No. 7, requiring each company to present an annual report that reveals the implementation of corporate governance and a description of the implementation of internal control and audit systems. This decision was made to prevent fraud, where disclosure of good quality internal control is inseparable from the role of the audit committee which has the task of establishing an accountable and transparent organisation (Capital Market and Financial Institution Supervisory Body, 2012). In line with that particular objective, an Act has also been issued, which is known as an Act of the chairman of Capital Market Supervisory Body KEP41/PM/2003. The Act highlights the obligation of public company to appoint audit committee, to possess audit work guidelines, regulation about accountability of audit committee to the board, and audit committee composition (that is, must have at least two (2) external members of the company (Capital Market and Financial Institution Supervisory Bodies, 2003).

As noted by the prior study, appointments of appropriate audit committee members can improve the quality of financial reports presented to the public (Pangaribuan et al., 2018). The quality of the internal control disclosure can be influenced by the size and character of the audit committee members (Setiany et al., 2017) and the expertise of the audit committee (Dewayanto et al., 2017). In addition, the audit committee oversees corporate governance, financial reporting processes, internal control structures, internal audit functions, and other externalities (Rezaee et al., 2003). In this case, the role of the audit committee can support the effectiveness of internal controls disclosure. The internal controls disclosure can indicate that the structure of control has been developed and implemented functionally by the company's management (Gao \& Huang, 2016). The Independent audit committee should support the quality of financial reports and improve 
the accuracy of the information in financial statements because the committee carries out an objective monitoring function without taking sides with any parties (Hundal, 2013).

When corporate governance improved and the audit committee functions in its oversight supervision are carried out optimally, then the quality of financial reporting will be better, the quality of disclosure will increase as well. The implementation of good corporate governance enhances the performance of independent audit committee members, so the oversight function runs smoothly and effectively, and disclosure of information for timely decision making will increase (Carcello \& Neal, 2003). Understanding of accounting is a matter that must be owned by audit committee members in carrying out their duties. To be able to find material errors in the financial statements, the audit committee must have knowledge and competence in accounting and finance, then one member of the audit committee must have an accounting or financial background and ability. Audit committees with the members who have competence in accounting and finance are expected to be able to produce reasonable and good quality of the financial report. Therefore, financial expertise is a big source for the audit committee (Baatwah et al., 2013).

To improve the quality of internal controls disclosure, supervision must be increased, including supervision upon quality management for reported profits, so that the quality of earnings gets better and better. In addition to the level of disclosure of internal controls, improving the quality of earnings is also related to the ability to predict future business profitability and cash flow. Therefore, supervision of managers must be increased to reduce the possibility of earnings manipulation, to improve earnings quality, and to increase the level of disclosure of internal control information (Leng \& Ji, 2011).

\subsection{Development of Hypotheses}

\subsubsection{Earnings Quality and Internal Control Disclosure}

The investors are aware that business contains inherent risks that can reduce earnings quality, so the investors are more interested in the companies that have good earnings quality. Earnings quality is also a measure used to assess the success of a business in achieving its operating objectives (Molaei et al., 2012). Before an investor decides to invest into a particular company, the first process is to analyze the company's ability to generate future earnings returns based on current earnings quality (Hamdan et al., 2013). Thus, companies need an internal control system to reduce risks that can harm the company. Internal control is a tool to reduce business risk and is also included in the supervision of reporting earnings quality (Ji et al., 2017). While the quality of earnings disclosed will affect investors' perceptions in assessing the market returns (Wang et al., 2015; Thornton \& He, 2013) so it can predict future earnings (Hamdan et al., 2013).

In addition to information transparency, the formation of an audit committee can also affect the level of earnings quality. The audit committee has a role in ensuring that the procedures and presentation of financial statements have been carried out in accordance with accounting standards and procedures. Profit presented in financial statements can be said to possess a good quality if it has a high level of reliability and trust (Wang et al., 2015). Leng and Li (2011) reveal that reported earnings quality can increase the internal control disclosure systems owned by companies, where companies with good earnings quality tend to reveal higher internal control because the conditions that occur presents the good news for various parties.

Companies that do disclosure based on Sarbanes-Oxley Act (2002) on internal control over financial reporting show that investor-perceived earnings quality are lower than companies that do not do it (Thornton \& He, 2013). However, the results of the study of 
Leng and $\mathrm{Li}$ (2011) state that earnings quality is an essential factor that influences the internal controls disclosure. The detail and extensive disclosure of internal control organisations show better market performance, especially companies with low discretionary accruals. In essence, companies with good earnings quality tend to make high information disclosures, including their internal controls disclosure (Weli, 2018). Based on the description, the hypothesis is formulated as follows:

$\mathrm{H}_{1}$ : Earnings quality has a significant effect on internal control disclosure of companies, all things being equal.

\subsubsection{Proportion of Independent Audit Committee and Internal Control Disclosure}

The audit committee is part of the company board of commissioners. One of the tasks is to ensure an independent auditor (Arens et al., 2014), and to help carry out the duties of supervisory the board (Financial Service Authority Regulation No.55 / POJK.04 / 2015). The establishment of an audit committee in having improvement to the audit quality of financial statements through excellent communication with external auditors and supervision of management in the presentation of financial statements (Hamdan et al., 2013). According to Bank Indonesia regulations (2006) No. 8/4/PBI/2006,) recommends that the audit committee (at least 51\%) are independent commissioners and independent parties. The member must have expertise in finance, accounting, law, or banking, and the chairman of the audit committee must be an independent commissioner member (Bank Indonesia, 2006).

Furthermore, Boyle et al., (2015) explain that the audit committee must have a diversity of independent members and leaders. In other words, the high proportion of independent audit committee members can increase the transparency and integrity of the companies disclosure (Madi et al., 2013; Salehi \& Mohammadamin, 2016), membership of independent audit committees can be improved to have better internal control disclosure system (Sun et al., 2012, \& Ahmad et al., 2015).

Independent audit committee members have a positive relationship with internal controls disclosure, independent audit committee members will perform more objective supervisory functions as well as to improve the quality of internal controls disclosure to the public (Zhou et al., 2010; Madi et al., 2013). Different results are expressed by Allegrini \& Greco (2013), which state that the proportion of audit committees has no relationship with voluntary disclosure. Chen et al. (2017) revealed that the level of independence of the board and the audit committee has a significant negative relationship with internal control disclosure reporting. Based on the results of the description, it is hypothesis as follows: $\mathrm{H}_{2}$ : The proportion of independent audit committees has a significant effect on internal control disclosure of companies, all things being equal.

\subsubsection{Financial Expertise of Audit Committee Member and Internal Control Disclosure}

The audit committee has a vital role in creating good corporate governance. The existence of an audit committee can protect shareholders from possible risks caused by fraudulent financial statements, corruption, and bribery (Deloitte, 2013). Therefore, the audit committee must use their ability to protect the company from harmful activities by conducting early supervision and detection of irregularities in its activities. In addition, an important point that must be considered for the audit committee is the level of activity to increase the transparency of the company so that the quality of its internal controls are considered adequate (Khlif \& Samaha, 2016). This shows that audit committees who are experts in their fields are significant and needed in the company. In other words, 
companies that have internal control weaknesses symbolise audit committee members are less skilled in and with poor knowledge of financial accounting and non-financial accounting (Zhang et al., 2007).

The audit committee has a vital role in the supervision of corporate financial reporting. The high number of meetings conducted by members of the audit committee is a reflection of better monitoring activities, primarily because of many of the outcome of decisions made for the purpose of monitoring and transparency of information ( $\mathrm{Li}$ et al., 2012). Audit committee expertise plays an important role in reducing the misappropriation of assets so that it will increase the accuracy of financial statement disclosures (Mustafa, 2010). Furthermore, the expertise of Audit committee reflects the effectiveness of the implementation of internal controls so that financial statements are more reliable (Dewayanto et al., 2017; Schmidt \& Wilkins, 2013). The results of the study by Mangena and Pike (2005) supported by Dewayanto, et al. (2017) state that audit committees that have accounting or financial expertise have a positive and significant influence on the internal control disclosure.

Other research also shows that there is a positive relationship between the financial experience of audit committee members and supervision and quality of disclosures in financial reporting (Hamdan \& Mushtaha, 2011). While in the previous study, it was found that there was a negative relationship between the audit committee expertise and the quality of financial statements due to the lack of supervision and disclosure (Bedard et al., 2004). Leng and Ding (2011) supported by Madi et al. (2013) also state that there was a negative relationship between internal control disclosure and the level of expertise of the audit committee and this was also in agreement with the results of the study of Setiany et al. (2017). Based on the description, the following hypothesis can be formed:

$\mathrm{H}_{3}$ : The financial expertise audit committee has a significant influence on internal controls disclosure of companies, all things being equal.

\subsubsection{Audit Committee Size and Internal Control Disclosure}

The audit committee plays an important role to assist the board in monitoring function of the company. The effectiveness of monitoring carried out by the audit committee in the financial reporting process greatly determines the high level of disclosures made by management to increase the trust of external parties upon management reports submitted to the public ( $\mathrm{Li}$ et al., 2012). Focusing on the importance of the audit committee, both large companies and small companies that have low financial reporting levels, must increase the size of their audit committee (Boyle et al., 2015).

The size of the audit committee is the number of all audit committee members who can support management supervision. A large number of sizes of audit committees is seen to increase management supervision in presenting credible financial reports. The size of a large audit committee can significantly reduce the practice of income smoothing and thus, improve the quality of earnings reports (Indrawan et al., 2018). Reliability of financial statements occurs because of the size of an extensive audit committee has the resources and ability to supervise and control management (Lin \& Hwang, 2010). In addition, the large size of the audit committee reflects the existence of a diversity of skills, perspectives, and skills that increase the company's voluntary disclosure (Madi et al., 2013). The formation of the audit committee is also related to its size, which reveals the opportunity to manipulate profits can be reduced, thus the quality of earnings increases with better disclosure of information to the public (Baxter \& Cotter, 2009).

At a different time, Mangena and Pike (2005) found that disclosure could not influence the size of the audit committee. Al-Shaer, Salama, and Toms (2017) state that the size of 
the board on the audit committee has little impact on the disclosure. Different results are shown by Madi et al., (2013), the higher the number of audit committee members with diverse expertise, views, and abilities, the better for good disclosure practices. Similar to the results of the company's research, Setiany et al. (2017) show that the size of the audit committee significantly influences the level of disclosure. Hence, the hypothesis is formulated:

$\mathrm{H}_{4}$ : Audit committee size has a significant effect on internal control disclosure of companies, all things being equal.

\section{RESEARCH METHOD}

This study is explanatory research with descriptive confirmatory analysis, which described and analyzed data based on existing facts. Then the results are interpreted, conclusions drawn, and relevant recommendations provided to the parties concerned in order to obtain benefits for future application.

\subsection{Population, Sample and Operationalization of the Variables}

Population is a generalization area that comprises objects or subjects that have certain qualities and characteristics of interest to the researchers. The population used in this research is banking companies in Indonesia that were registered in IDX for the period 2013-2017. This study used purposive sampling in determining the research sample, with the criteria that the company is a bank listed on the Indonesia Stock Exchange, which publishes their full annual report between 2013 and 2017 and conveyed information related to each variable that has been researched.

There were 43 banks listed on the Indonesia Stock Exchange during the years of observation in this study. Out of which 8 banks that did not meet the criteria for the study (that is, incomplete annual reports) because the banks were new and listed on the Indonesia Stock Exchange after 2013. The unit of analysis is Banks listed in IDX, and the research samples consist of 35 banks for a 5-year observation period (that is, from 2013 to 2017). Thus, the study used 175 annual reports for further analysis of each research variable.

This study comprises a dependent variable that has a significant influence on the independent variables. The dependent variable is represented by internal controls system disclosure, while the independent variable comprises earnings quality as proxied by accruals discretion, independent audit committee, financial expertise of the audit committee and audit committee size. The description of variables and measurements is presented in Table 1.

\subsection{Data Collection and Processing Technical}

This study used secondary data. Data for each variable was collected from the company's annual report for the period from 2013 to 2017 through internet media download from the official IDX website. This research upholds ethical standards and did not aim to discredit certain parties with the findings. However, the results aim to provide practical input to various parties for future improvement.

Data for the internal control disclosure system identified the controls (test of controls) the companies adopted to reflect the effectiveness of the company's internal controls (Leng \& Ding, 2011). The internal control disclosure system was observed through the company's annual report about corporate governance, which was an integral part of the 
company's internal control system. In this study, there were six measurement indicators relating to the internal control disclosure system. The indicators include the contents of the internal control system, the implementation of the internal control system, the role of the internal control system, the objectives of the internal control system, the internal control system framework, and the presentation of internal control disclosure system (Setiawan, 2016). The list of companies' internal control disclosure system index can be found in Appendix 1. Data collection for the internal control disclosure systems was done by content analysis and measured by using scoring techniques, ranking "1" for each index disclosed and "0" for each index not disclosed. Next following by dividing the total index expressed by the maximum value of all index with the formula as depicted in Table 1 . The measurement of disclosure of the internal control system in this study used Setiawan (2016) approach. This approach is seen as acceptable as it exceeds the benchmark criteria set by the Capital Market Supervisory Body through Kep-431/BL/2012 No. X.K, Article 2.

The earnings quality in this study used a discretionary accruals value model in accordance with previous research, the large value of discretionary accruals shows low earnings quality and vice versa. The formula for calculation of discretionary accruals is highlighted in Table 1. Independent audit committees were measured based on the proportion of independent audit committees. It is calculated on the number of independent audit committee members divided by the total number of audit committee members. The Financial Expertise audit committee was one of the requirements in the audit committee membership; the audit committee must have at least one member who is an expert in accounting or finance. The financial expertise of the audit committee was measured by the number of members in the audit committee who have an accounting or financial education background, and divided by the total members of the audit committee. The size of the audit committee was measured by the number of audit committee members in the company concerned.

Data analysis was carried out by describing descriptive data, correlation coefficients, determination coefficients of significance tests and linear regression for further interpretation. The linear regression model is expressed as follows:

$$
\text { ICD }=\alpha+\beta_{1} \text { Discr_Accrl }+\beta_{2} \text { AC_Ind }+\beta_{3} \text { AC_Fin_Exp }+\beta_{4} \text { AC_Size }+\varepsilon
$$

where,

\begin{tabular}{|c|c|}
\hline ICD & : Internal control disclosure \\
\hline$\alpha$ & : Constanta \\
\hline$\beta_{1}, \beta_{2}, \beta_{3}, \beta_{4}$ & $\begin{array}{l}\text { : Regression coefficient for earnings quality, independent audit } \\
\text { committee,financial expertise audit committee, audit committee } \\
\text { size }\end{array}$ \\
\hline Discr_Accrl & : Earnings quality \\
\hline$A C \_$Ind & : Independent audit committee \\
\hline$A^{-}$Fin Exp & : Financial expertise audit committee \\
\hline AC_Sizēe & : Audit committee size \\
\hline$\varepsilon$ & : error \\
\hline
\end{tabular}


Table 1. Variables' Measurement

\begin{tabular}{|c|c|c|}
\hline Variable & Measurement & Scales \\
\hline $\begin{array}{l}\text { Internal control disclosure } \\
\text { system (dependent } \\
\text { variable) }\end{array}$ & $\begin{array}{l}\text { DISC }=\frac{\sum I C D}{\sum M I C D} \\
\text { Where: } \\
\text { DISC : internal control disclosure } \\
\sum I C D: \text { Total index of internal control disclosed } \\
\sum \text { MICD: Total maximum internal control disclosure } \\
\text { index } \\
\text { (Van \& Vanstraelen, 2011) }\end{array}$ & Ratio \\
\hline $\begin{array}{l}\text { Earnings quality } \\
\text { (independent variable) }\end{array}$ & 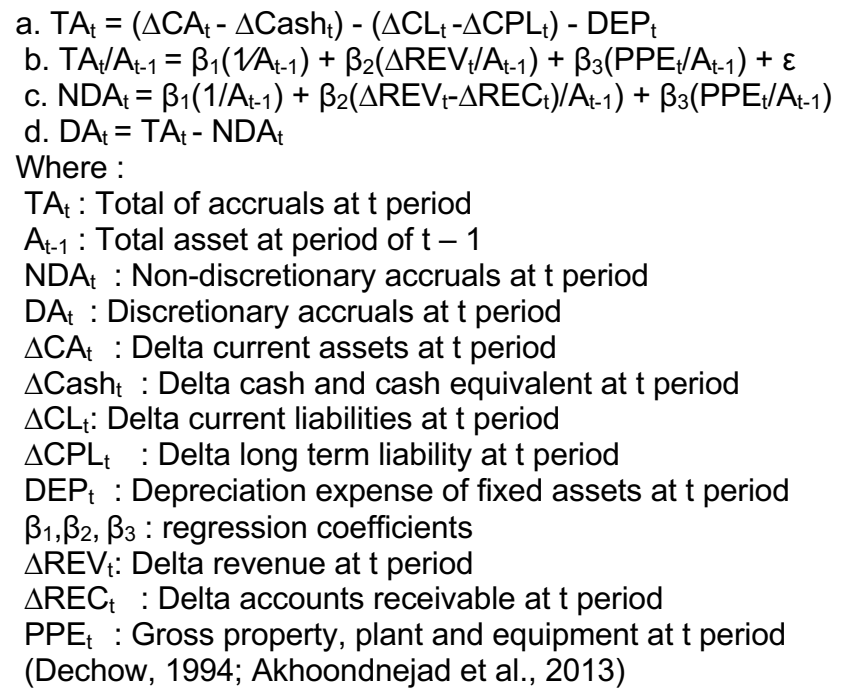 & Ratio \\
\hline $\begin{array}{l}\text { Independent audit } \\
\text { committee (independent } \\
\text { variable) }\end{array}$ & $\begin{array}{l}\text { Proportion of independent audit committee }= \\
\frac{\sum \text { independent audit committee }}{\sum \text { member of audit committee }} \times 100 \% \\
\text { (Hamdan et al., 2013) }\end{array}$ & Ratio \\
\hline $\begin{array}{l}\text { Financial expertise audit } \\
\text { committee (independent } \\
\text { variable) }\end{array}$ & $\begin{array}{l}\text { Financial expertise audit committee }= \\
\frac{\sum \text { Aud.Committee expert in finance }}{\sum \text { member of audit committee }} \times 100 \% \\
\text { (Hamdan et al., 2013) }\end{array}$ & Ratio \\
\hline $\begin{array}{l}\text { Audit committee size } \\
\text { (independent variable) }\end{array}$ & $\begin{array}{l}\text { Audit committee size }= \\
\sum \text { Members of audit committee } \\
\text { (Lin et al., 2006) }\end{array}$ & Ratio \\
\hline
\end{tabular}

\section{RESULTS AND DISCUSSION}

Data analysis was carried out by describing descriptive data, correlation analysis between independent and dependent variables, then the significance test and regression analysis were interpreted to provide constructive input and suggestions for various parties.

\subsection{Descriptive Analysis}

The descriptive statistics in Table 2 showed that the amount of data observed, $N=175$ was for 35 banks throughout the five years of observation, 2013-2017. Data showed that there was a tendency for banking companies in Indonesia to report their profits that were smaller than they should be, this was indicated by the minimum value of discretionary 
accruals of -0.51 , the maximum value of 0.14 and the average value of -0.0301 . The companies reported smaller profits with the objective of minimizing political costs such as tax and other social responsibility costs (Akhoondnejad et al., 2013).

There were six measurement indicators related to the internal control disclosure system, which were the content of internal control system, the implementation of the internal control system, the internal control system and its role, the objective of internal control system, the frame of work of the internal control system and the separation section on internal control system. There were 27 items of internal control disclosure index from six existing indicators (those 27 indexed items can be found in Appendix 1). The results showed that on average, only about 36 per cent of companies disclose the internal control disclosure index with a minimum value of 4 per cent and a maximum value of 78 per cent. The standard deviation value smaller than the average value showed a useful data variable.

Financial services authority regulation stipulated that any public companies must form audit committees with three members as a minimum and to be chaired by independent board commissioners. In essence, at least one of the audit committees must be independent. The data in Table 2 showed that Indonesian banking companies had fulfilled the requirements set by the financial services authority regulation by having at least one independent member of the audit committee. It was found that some banks also maintained members of the audit committee who were independent. This was done to supervise the process of presenting financial statements to be better, the disclosure will be more adequate, and reported quality of earnings will be more reliable (Gao \& Huang, 2016).

Table 2. Descriptive Statistics

\begin{tabular}{lllllll}
\hline & $\mathbf{N}$ & Minimum & Maximum & Mean & Std. Deviation Variance \\
\hline Discr_Accrl & 175 & -.51 & .14 & -.0301 & .08236 & .007 \\
ICD_Index & 175 & .04 & .78 & .3597 & .18998 & .036 \\
AC_Ind & 175 & .33 & 1.00 & .7750 & .28277 & .080 \\
AC_Fin_Exp & 175 & .25 & 1.00 & .5487 & .25026 & .063 \\
AC_Size & 175 & 3.00 & 8.00 & 3.8800 & 1.07874 & 1.164 \\
Valid N (listwise) & 175 & & & & & \\
\hline
\end{tabular}

The results of AC_Fin_Exp in Table 2 with a value of 0.25 (i.e. mean, 0.5487 ) indicated that each bank has at least one member of the audit committee with expertise in finance or accounting. This revealed that the audit committee had better expertise in conducting supervision, including the company's internal controls disclosure in the financial statements. The study also recommended that the existing banking companies should meet the requirements of having a minimum of three members of the audit committee. This is important in order to achieve the best practices in oversight supervision of the banking sector. The standard deviation value of an independent audit committee, financial expertise and the size of a small audit committee from the average value indicated a good distribution of the data for the three variables.

\subsection{The Correlation and Determination Coefficient Tests}

The results of the correlation test among variables are illustrated in Table 3 . The findings revealed a positive and moderate correlation between discretional accruals with the internal control disclosure systems. In essence, an evident increase in the value of discretional accruals (means a decrease in earnings quality) coupled with the direction of its movement, increasing the internal control disclosure systems. Management tends to disclose an internal control system (to maintain public trust) for the decline in the quality 
of earnings. This finding is in line with the results of previous study stating that there was a negative relationship between earnings quality with disclosure of internal control system (Thornton \& He, 2013).

It has also been found that there was a positive and moderate correlation between independent audit committees with the internal control disclosure systems. Similarly, there was a positive and moderate correlation between the financial expertise of the audit committee and the internal control disclosure systems. However, the relationship between the internal control disclosure systems and the size of the audit committee indicated a positive and weak correlation. This study provided consistent empirical evidence to support the effect of the characteristics of the audit committee on the increased disclosure of the company's internal control systems.

Table 3. Correlations

\begin{tabular}{llllll}
\hline & ICS_Discl_Index & Discr_Accrl & AC_Ind & AC_Fin_Exp & AC_Size \\
\hline ICS_Discl_Index & 1.000 & .403 & .516 & .446 & .014 \\
Discr_Accrl & .403 & 1.000 & .388 & .167 & .058 \\
AC_Ind & .516 & .388 & 1.000 & .226 & -.101 \\
AC_Fin_Exp & .446 & .167 & .226 & 1.000 & -.070 \\
AC_Size & .014 & .058 & -.101 & -.070 & 1.000 \\
\hline
\end{tabular}

The results of the Coefficient of Determination as presented in Table 4 showed that 40.7 percent of the internal control disclosure systems could be determined by the quality of earnings, the independent audit committee, the financial expertise of the audit committee and the size of the audit committee.

Table 4. The Coefficient of Determination Result

\begin{tabular}{lllll}
\hline Model & $\mathbf{R}$ & $\mathbf{R}$ Square & Adjusted R Square & Std. Error of the Estimate \\
\hline $.648^{\mathrm{a}}$ & .421 & .407 & .14631
\end{tabular}

Similarly, the regression model results in this study indicated that companies with high levels of discretional accruals have the potentials to make significant disclosure of internal control systems. The effect of gathering relevant and valid information, and obtaining reliable evidence to provide reasonable assurance with to the users of the financial statements could not be over-emphasised.

The regression model also described the characteristics of audit committees as an influencing agent or catalyst to the internal control systems disclosure. Companies with a large proportion of independent audit committee members tended to do more internal control systems disclosure than those with a small size. The more the effectiveness of the oversight functions of the audit committee on internal control systems disclosure, the better for the management and other users of the financial statements in terms of transparency and accountability in companies.

$$
\mathrm{ICD}=.90+.463 \text { Discr_Accrl }+.248 \text { AC_Ind }+.253 \text { AC_Fin_Exp }+.011 \text { AC_Size }+\varepsilon
$$

The findings of this study also indicated companies with audit committees that comprise experts in finance and accounting performed excellently in its oversight supervisory functions than companies no audit committee experts. The reasons adduced for this position may perhaps stem from professional skills and knowledge about the financial reporting process of the audit committee members. Furthermore, the regression model of this study highlights companies with large audit committee members conduct oversight supervision increasing internal control disclosure systems, thus enhancing the relevant 
and reliable information presented to the users of financial statements for decision-making purposes.

\subsection{Results of Hypotheses Testing}

The results of hypotheses testing shown in Table 5 provide the conclusion that banking companies in Indonesia with high total discretionary accrual (low earnings quality) can significantly influence the high level of the internal control disclosure system. This revelation supports the hypothesis $\mathrm{H}_{1}$, which states: Earnings quality has a significant effect on internal control disclosure of companies, all things being equal with a value of $\beta$ $=.463, \mathrm{t}=3.140, \mathrm{p}=.002$. The interpretation is that companies with good earnings quality conveyed less information about the internal control system disclosure. The findings have the potentials to support management assertion about the quality of reported earnings and its implications to stakeholders. Thus, highlighting the efficient management of resources and effective supervision. Hornton and He (2013) study demonstrated that investors' opinions and feelings about companies with high earnings quality did not constitute a disclosure of high internal control system.

Table 5. Regression Testing Results

\begin{tabular}{lllllll}
\hline & \multicolumn{3}{c}{$\begin{array}{l}\text { Unstandardized } \\
\text { Coefficients }\end{array}$} & $\begin{array}{l}\text { Standardized } \\
\text { Coefficients }\end{array}$ & Hypotheses \\
\hline Model & B & Std. Error & Beta & t & Sig. & \\
\hline (Constant) & .090 & .062 & & .002 & .998 & \\
Discr_Accrl & .463 & .148 & .201 & 3.140 & .002 & supported \\
AC_Ind & .248 & .044 & .369 & 5.683 & .000 & supported \\
AC_Fin_Exp & .253 & .046 & .333 & 5.532 & .000 & supported \\
AC_Size & .011 & .010 & .063 & 1.058 & .292 & not- supported \\
\hline
\end{tabular}

Subsequent results showed that companies with a high composition of independent audit committee members significantly influence the high level the internal control disclosure system. This showed hypothesis $\mathrm{H}_{2}$ which states thus: The proportion of independent audit committees has a significant effect on internal control disclosure of companies, all things being equal is confirmed and supported with a value of $\beta=.248, t=5.683, p=.000$. The significant composition of independent audit committee members had impacted on the objective supervision of the financial reporting process, including the disclosure information to the public. Hence, the asymmetric information level of the internal control disclosure systems is high and enjoying wider acceptability between the management and users of the financial statements. This study aligned with previous studies that revealed a significant and positive correlation between independent audit committee on internal control disclosure systems (Zhou et al., 2010; Madi et al., 2013; Salehi \& Mohammadamin, 2016).

Most importantly, the results revealed that companies with audit committees' expertise in finance or accounting significantly influence the internal controls disclosure system. The hypothesis $\mathrm{H}_{3}$ that states: The financial expertise audit committee has a significant influence on internal controls disclosure of companies, all things being equal is supported with a value of $\beta=.253, t=5.532, p=.000$. The existence of audit committee members who were experts in finance or accounting gave better attention to financial reporting supervision and the level of the internal control disclosure systems in the banking companies. The current study results are consistent with Hamdan and Mushtaha (2011) study, which had a positive and significant impact of the financial and accounting experience of audit committee members on disclosures internal controls system. 
The results of hypothesis testing indicated that the size of the audit committee posits a negative significant effect on the disclosure of an internal controls system in relation to the annual reports of banking companies. The hypothesis $\mathrm{H}_{4}$ that states: Audit committee size has a significant effect on internal control disclosure of companies, all things being equal is not confirmed and supported with a value of $\beta=.011, t=1058, p=.292$. The finding of this study is consistent with Mangena and Pike (2005) study, which affirmed the size of the audit committee has no significant association on disclosure of the internal controls system. In essence, the audit committee's supervisory functions on the disclosure of internal control system could not relate to the size of the audit committee members but instead relate positively by the expertise in finance and accounting, and the independence in fact and appearance of the audit committee members.

\section{LIMITATIONS AND FUTURE RESEARCH SIGNPOST}

This study, based on a model, has its limitations like any other studies, which depends on assumptions. First, the issue of selecting certain variables and measuring indicators might have an influence or effect on the internal control disclosure systems.

Second, the peculiarity of Indonesian Stock Exchange listing requirements on the banking sector could be a potential cause of limitations in comparison with other countries in Asia, especially and the world in general.

This study recommends future research on other variables such as organizational commitment, the external auditors' role on the internal control disclosure systems. Most importantly, a model based on the interaction effect of organizational commitment on the relationship between the quality of earnings, the independent audit committee, the financial expertise of the audit committee, and the size of the audit committee on the internal control disclosure systems is desirable.

Similarly, the study suggests a research model anchored on the mediating impact of the external auditors' role on the relationship between the quality of earnings, the independent audit committee, the financial expertise of the audit committee and the size of the audit committee on the internal control disclosure systems.

Furthermore and most interesting would be a research model based on the mediatedmoderation and/or moderated-mediation of external auditors' role and organisational commitment on the association between the quality of earnings, the independent audit committee, the financial expertise of the audit committee and the size of the audit committee on the internal control disclosure systems.

\section{CONCLUSION}

The study findings revealed from the respondent's companies an adequate internal control system disclosure. However, about $5 \%$ of the respondent's companies indicated a low level of effectiveness of internal controls system disclosure. This study recommends that effective and efficient monitoring and control are required from the audit committee to ensure management implementation and disclosure of the company's internal control systems. The current study aligns with previous studies on proper presentation and disclosure requirements, which are essential to the users of the financial report or information by the management. The role of the external auditor is also significant regarding the quality of reported earnings on the one hand, and the disclosure and implementation of the internal control system are sufficiently implemented on the other hand.

The study revealed users' confidence and trust in the information conveyed by the management when adequate internal control systems disclosure is put in place. An 
adequate internal control systems disclosure presupposes financial statements presented by the management is free from misstatements that may occur due to fraud or errors. Monitoring efforts in the financial reporting process and internal control disclosure systems can be better determined by the quality of audit committee members who have the expertise in finance or accounting as well as espousing independence in fact and appearance. Similarly, the supervisory oversight function posited a negative relationship between the size of the existing audit committee and the quality of the internal control systems disclosure.

\section{REFERENCES}

Agyei-Mensah, B. K. (2016). Internal Control Information Disclosure and Corporate Governance: Evidence From an Emerging Market. Corporate Governance: The International Journal of Business in Society, 16(1).

Ahmad, R., A., R., Abdullah, N., Jamel., N., E., S., M., \& Omar., N. (2015). Board Characteristics and Risk Management and Internal Control Disclosure Level: Evidence from Malaysia. Procedia Economics and Finance, 31, pp 601-610. doi: 10.1016/S2212-5671(15)01147-8

Akhoondnejad, J., M. Garkaz, \& M. Shoorvazi. (2013). Political Cost Factors Affecting Income Smoothing Evidence from Tehran Stock Exchange (TSE). Interdisciplinary Journal of Contemporary Research in Business. 5 (2). $341-350$.

Allegrini, M., \& Greco, G., (2013). Corporate Board, Audit Committee, and Voluntary Disclosure: Evidence from Italian Listed Companies. Springer Science \& Business Media, 17, 187-216. doi: 10.1007/s10997-011-9168-3.

Al-Shaer, H., Salama, A., \& Toms, S. (2017). Audit Committees and Financial Reporting Quality: Evidence from UK Environmental Accounting Disclosure. Journal of Applied Accounting Research, 18(1), 1-37.

Arens, A. A., Beasley, M. S., \& Elder, R. J. (2014). Auditing and Assurance Services: An Integrated Approach. $15^{\text {th }}$ ed.

Asian Development Bank. (2014). ASEAN Corporate Governance Scorecard Country Reports and Assessments 2013-2014.www.theacmf.org/ACMF/upload/asean_cg_scorecard.

Baatwah, S., Salleh, Z., \& Ahmad, N. (2013). Whether Audit Committee Financial Expertise Is The Only Relevant Expertise: A Review of Audit Committee Expertise and Timeliness of Financial Reporting. Issues in Social and Environmental Accounting, 7(2), 86-101.

Bank of Indonesia. (2006). Bank Indonesia Regulation No. 8/4/PBI/2006 Implementation of Good Corporate Governance for Commercial Banks.

Bedard, J., Chtourou, S. M., \& Courteau, L. (2004). The Effect of Audit Committee Expertise, Independence, and Activity on Aggressive Earnings Management. Auditing: A Journal of Practice \& Theory, 23(2), 13-35.

Billet, M. T., Garfinkel, J. A., \& Yu, M. (2016). The Effect of Asymmetric Information on Product Market Outcomes. Journal of Financial Economics, 1-20.

Boddy, C. R. (2017). Enron Scandal. Encyclopedia of Business and Professional Ethics. 1, 1-4. doi: 10.1007/978-3-319-23514-1_2-1.

Boyle, J. F., Gramling, A. A., Hermanson, D. R., \& Hermanson H. M. (2015). Audit Committee Material Weakness in Smaller Reporting Companies: Still Struggling. Journal of Forensic \& Investigative Accounting, 7(1), 110-121.

Capital Market and Financial Institution Supervisory Bodies. (2003). Regulation No. IX.1.5 Chairperson Resolution, BAPEPAM-LK No. KEP-41/PM/2003. Concerning Establishment and Implementation of Audit Committee Guidelines. Jakarta: Bapepam-LK.

Capital Market and Financial Institution Supervisory Bodies. (2012). Chairperson Resolution BAPEPAM-LK No. KEP-431/BL/2012 Concerning Annual Report Submission of Public Companies. Jakarta: Bapepam-LK.

Carcello, J. V., \& Neal, T. L. (2003). Audit Committee Independence and Disclosure: Choice for Financially Distressed Firms. Corporate Governance: An International Review, 11(4), 289299. 
Cavelius, F., (2011). Opening The "Black Box": How Internal Reporting Systems Contribute to The Quality of Financial Disclosure. Journal of Applied Accounting Research, 187-211.

Chen, Y., Knechel, W., R., Marisetty, V., B., \& Truong, C. (2017). Board Independence and Internal Control Weakness: SOX 404 Disclosure. Auditing: A Journal of Practice \& Theory, 36(2), 4562. doi: 10.2308/ajpt-51577.

Cheng, M., Dhaliwal, D., \& Zhang, Y. (2013). Does Investment Efficiency Improve After the Disclosure of Material Weaknesses in Internal Control Over Financial Reporting. Journal of Accounting and Economics, 56(1).

Choi, F. D., \& Meek, G. K., (2011). International Accounting (7 ed.). Pearson.

Dechow, P. M., (1994). Accounting Earnings and Cash Flows as Measures of Firm Performance: The Role of Accounting Accruals. Journal of Accounting and Economics. 18, 3-42.

Deloitte. (2013). Guarding against Fraud and Corruption: The Audit Committee's Role. Available at http://deloitte.wsj.com/cfo/2013/09/04/guarding-against-fraud-and-corruption-the-auditcommittees-role/.

Dewayanto, T., Suhardjanto, D., Bandi, \& Setiadi, I., (2017). Ownership Structure, Audit Committee, and Internal Disclosure: Indonesia and Philippines. Review of Integrative Business \& Economics Research, 6(4)

Financial Service Authority Body. (2015). Financial Services Authority Regulation No. 55/POJK.04/2015. About Establishment and Guidelines for Implementation of Audit Committee Work. Jakarta: Financial Services Authority.

Gad, J., (2015). Disclosures on Control Over Financial Reporting: The Reporting Practice of Banks Listed on The WSE. Financial Internet Quarterly, 1, 1-10.

Gao, H., \& Huang, J., (2016). The Even-Odd Nature of Audit Committees and Corporates Earnings Quality. Journal of Accounting, Auditing, \& Finance, 1-15.

Godfrey, J., Hudgson, A., Tarca, A., Hamilton, J., \& Holmes, S. (2010). Accounting Theory (7 ed.). New York: John Wiley \& Sons.

Grant Thornton LLP. (2009). Monitoring the system of internal control: The Audit Committee Guides Series. Chicago: Grant Thornton LLP.

Guo, X., \& Liu, W., (2015). Internal Control Weakness Discloser and Earnings Management. Proceedings of $4^{\text {th }}$ Conference on Logistics, Informatics, and Service Science, pp. 869-876.

Hamdan, M. M. A., \& Mushtaha, S. M. S. (2011). The Relationship between Audit Committee Characteristics and Type of Auditor's Report: An Empirical Study on the Public Shareholding Industrial Companies Listed at Amman Bourse. The Arabian Journal of Accounting, 14(1), 109-163.

Hamdan, M.M.A., Mustaha, S.M.S., \& Al-Sartawi, M.A.A. (2013). The Audit Committee Characteristics and Earnings Quality: Evidence from Jordan. Australasian Accounting Business and Finance Journal, 7(4), 51-80.

Hooghiemstra, R., Hermes, N. \& Emanuels, J. (2015). National culture and internal control disclosures: a cross-country analysis. Corporate Governance: An International Review. 23(4), 357-377.

Hundal, S., (2013). Independence, Experience of Audit Committees Some Aspects of Indian Corporate Sector. American International Journal of Social Science, 2(5).

Indrawan, V., Agoes, S., Pangaribuan, H., \& Popoola, O.M.J. (2018). The Impact of Audit Committee, Firm Size, Profitability, and Leverage on Income Smoothing. Indian-Pacific Journal of Accounting and Finance, 2(1), 61-74.

Ismail, T. H., \& El-Shaib, N. M. (2012). Impact of Market and Organizational Determinants on Voluntary Disclosure in Egyptian Companies. Mediterranean Accounting Research, 113133.

Ji, X., Lu, W., \& Qu, W., (2017). Voluntary Disclosure of Internal Control Weakness and Earnings Quality: Evidence from China. The International Journal of Accounting. 52(1), 27-44. doi: 10.1016/j.intacc.2017.01.007.

Khlif. H., \& Samaha, K. (2016). Audit Committee Activity and Internal Control Quality in Egypt: Does External Auditor's Size Matter? Managerial Auditing Journal, 31(3), 1-37.

Leng, J., \& Ding, Y. (2011). Internal Control Disclosure and Corporate Governance: Empirical Research from Chinese Listed Companies. Technology and Investment, 286-294. 
Leng, J., \& Li, L., (2011). Analysis of The Relationship Between Listed Companies Earnings Quality and Internal Control Information Disclosure. Modern Economy. 2, 893-900.

Lin, J. W., Li, J. F., \& Yang, J. S. (2006). The Effect of Audit Committee Performance on Earnings Quality. Managerial Auditing Journal, 21(9), 921-933.

Madi, H., K., Ishak, Z., \& Manaf., N., A., A. (2013). Audit Committee Characteristics and Voluntary Disclosure: Evidence from Malaysian Listed Firms. Terengganu International Finance and Economics Journal, 3(1), 14-21.

Mangena, M., \& Pike, R., (2005). The Effect of Audit Committee Shareholding Financial Expertise and Size on Interim Financial Disclosure. Accounting and Business Research, 35(4), 327349, doi: 10.1080/00014788.2005.9729998.

Mensah, B. K. A., (2016). Internal Control Information Disclosure and Corporate Governance: Evidence from an Emerging Market. The International Journal of Business in Society, 16(1), 79-95.

Molaei, I., Molaei, D., Yari, R., \& Aghabaki, M. (2012). The Investigation of Effecting Factors on Earnings Quality. Journal of Basic and Applied Scientific Research, 2(3), 3077-3080.

Mustafa, S., T, \& Youssef, N., B. (2010). Audit Committee Financial Expertise and Misappropriation of Asset. Managerial Auditing Journal, 25(3), 208-225. doi: 10.1108/0268690101 1026323.

Paletta, A., \& Alimehmeti, G., (2016). SOX Disclosure and The Effector of Internal Controls on Executive Compensation. Journal of Accounting, Auditing, \& Finance, 1-19. doi: 10.1177/0148558X16630445.

Pangaribuan, H., Sihombing, J., \& Popoola, O.M.J., (2018). Examining the Independent Audit Committee, Managerial Ownership, Independent Board Member and Audit Quality in Listed Banks. Indian-Pacific Journal of Accounting and Finance, 2(2), 4-23.

Rezaee, Z., Olibe, K., O., \& Minmier, G. (2003). Improving Corporate Governance: The Role od Audit Committee Disclosure. Managerial Auditing Journal, 18(6/7), 530-537.

Romney, M. B., \& Steinbart, P. J. (2012). Accounting Information System.. $12^{\text {th }}$ Edition. New York: Pearson.

Russo, A., Herdan, A., \& Neri, L. (2015). Empirical Evidence on Internal Control Disclosure in Italy Stock Exchange and the Polish Stock Exchange. Krakow: Fundacja Uniwersytetu Ekonomicznego w Krakowie, 379-388.

Said, R., Zainuddin, H. Y., \& Haron, H. (2009). The Relationship between Corporate Social Responsibility Disclosure and Corporate Governance Characteristics in Malaysian Public Listed Companies. Social Responsibility Journal. Vol. 5. No. 2, Pp. 212-226.

Salehi, M., \& Mohammadamin, S., (2016). Audit Committee Impact on the Quality of Financial Reporting and Disclosure: Evidence from the Tehran Stock Exchange. Management Research Review, 39(12), 1639-1662, doi: 10.1108/MRR-09-2015-0198.

Scott, W. R., (2003). Financial Accounting Theory-Prentice Hall (3 ed.). Canada: Prentice-Hall Canada, Inc. Scarborough: Ontario.

Setiany, E., Hartoko, S., \& Suhardjanto, D. (2017). Audit Committee Characteristics and Voluntary Financial Disclosure. Review of Integrative Business \& Economics Research, 6(3), 239-253.

Setiawan, A., (2016). The Impact of Internal and External Factors on Internal Control Disclosure System. Dissertation, Parahyangan Catholic University.

Schmidt, J., \& Wilkins, M., S. (2013). Bringing Darkness to Light: The Influence of Auditor Quality and Audit Committee Expertise on the Timeliness of Financial Statement Restatement Disclosure. Auditing Journal of Practice \& Theory, 32 (1), 221-224.

Siagian, T. F., \& Tresnaningsih, E. (2011). The Impact of Independent Directors and Independent Audit Committees on Earnings Quality Reported by Indonesian Firms. Asian Review of Accounting, 19(3), 192-207.

Spira, L. F., \& Page, M. (2010). Regulation by Disclosure: The Case of Internal Control. Journal of Management, 409-433.

Sun, Y., Yi., Y., \& Lin, B.(2012). Board Independence, Internal Information Environment and Voluntary Disclosure of Auditors' Report upon Internal Controls. China Journal of Accounting Research, 5, 145-161. doi: 10.1016/j.cjar.2012.05.003.

Suprianto, E., Suwarno, S., Murtini, H., Rahmawati, R. \& Sawitri, D. (2017). Audit Committee Accounting Expert and Earnings Management with "Status" Audit Committee as Moderating Variable. Indonesian Journal of Sustainability Accounting and Management, 1(2), 49-58. 
Teoh, S. H., \& Wong, T. J., (1993). Perceived Auditor Quality and the Earnings Response Coefficient. The Accounting Review, 68(2), 346-366.

Thornton, B. D., \& He, L. (2013). The Impact of Disclosures of Internal Control Weaknesses and Remediation on Investors' Perceptions of Earnings Quality. Accounting Perspectives. 12(2), 101-139.

Vakilifard \& Mortazavi. (April 2016). The Impact of Financial Leverage on Accrual Based and Real Earning Management. International Journal of Academic Research in Accounting, Finance and Management Sciences, 6 (2), 53-60.

Van de Poel, K., \& Vanstraelen, A. (2011). Management Reporting on Internal Control and Accruals Quality: Insights from A "Comply-or-Explain" Internal Control Regime. Auditing: A Journal of Practice \& Theory, 30(3), 181-209.

Wang, M., C., Lee, M., H., \& Chuang, J., J. (2015). Relation Among Audit Committee Establishment Information Transparency and Earnings Quality: Evidence from Simultaneous Equation Models. Springer Science \& Business Media Dordrecht, 50, 2417-2431. doi: 10.1007/s11135-015-0269-y.

Weli \& Sjarief, J., (2018). The Effect of Internal Control Discloser on Financial Information Quality and Market Performance distinguished by the Corporate Governance Index. International Journal of Accounting and Financial Reporting, 8(1), 241-260.

Zhang, Zhou, J., \& Zhou, N. (2007). Audit Committee Quality, Auditor Independence, and Internal Control Weaknesses. Journal of Accounting and Public Policy, 26, 300-327.

Zhou, C., Song, C., Zhao, Y., \& Chen, X. (2010). Research on The Quality and Evaluation of Government Auditing Information Disclosure. Contemporary Finance and Economic, 7. 
Appendix 1. Internal Control System Disclosure Index

\begin{tabular}{|c|c|c|}
\hline No & Group & Group details \\
\hline \multirow[t]{11}{*}{1} & Internal control system & Control environment \\
\hline & (ICS) content & Risk management \\
\hline & & Control activity \\
\hline & & Information and communication \\
\hline & & Supervision \\
\hline & & Objective \\
\hline & & Responsible \\
\hline & & Financial control \\
\hline & & Operational control \\
\hline & & Compliance with regulations \\
\hline & & Review of ICS \\
\hline \multirow[t]{6}{*}{2} & Implementation of ICS & Organizing ICS in general \\
\hline & & Evaluation the effectiveness of ICS \\
\hline & & Periodic supervision \\
\hline & & Significant weakness \\
\hline & & Internal monitoring \\
\hline & & External supervision \\
\hline \multirow[t]{5}{*}{3} & ICS and its role & The supervisory function by the board \\
\hline & & Supervision by the audit committee \\
\hline & & Organizing function by the board of directors \\
\hline & & Organizing function by the board of directors \\
\hline & & $\begin{array}{l}\text { The auditor's responsibility for ICS is related to financial } \\
\text { reporting }\end{array}$ \\
\hline \multirow[t]{2}{*}{4} & The objective of ICS & $\begin{array}{l}\text { Objectives related to the reliability of financial statements } \\
\text { Objectives related to the effectiveness and efficiency of } \\
\text { operations }\end{array}$ \\
\hline & & Objectives related to compliance with the laws and regulations \\
\hline 5 & The frame-work of ICS & $\begin{array}{l}\text { The ICS framework is as a reference in companies, for example, } \\
\text { COSO, ERM, ISO and COBIT }\end{array}$ \\
\hline 6 & $\begin{array}{l}\text { A separate section on } \\
\text { ICS }\end{array}$ & $\begin{array}{l}\text { Conduct ICS disclosures in a separate subpart in the corporate } \\
\text { governance section of the company's annual report. }\end{array}$ \\
\hline
\end{tabular}

Source: Setiawan (2016) 